\title{
ХУДОЖНЬО-ПРОЕКТНА ДІЯЛЬНІСТЬ ЯК ПРОВІДНИЙ ЗАСІБ РОЗВИТКУ ТВОРЧИХ ЗДІБНОСТЕЙ МАЙБУТНІХ ДИЗАЙНЕРІВ
}

\author{
Marina TIMCHENKO, postgraduate department of pedagogy Zhytomyr \\ Ivan Franko State University
}

\section{ARTISTIC DESIGN AS A LEADING WAY OF DEVELOPING OF FUTURE DESIGNER}

У статті репрезентується проблема розвитку творчих здібностей; акцентується увага на необхідності розвитку індивідуальної творчості в майбутніх дизайнерів; здійснено аналіз художньо-проектної діяльності як прогресивного методу розвитку творчих здібностей майбутніх фахівців у сфері дизайну; наголошується на важливості розвиту творчих здібностей майбутніх дизайнерів у процесі їх фахової підготовки.

Ключові слова: художньо-проектна діяльність, здібності, творчі здібності, творчість, метод проектів, майбутній дизайнер.

Summary. In this article the problem of development of creative skills is represented. The special accent is on a necessity of development of an individual creativity of future designers. Artistic design was analyzed as a progressive method of development of creative skills of future designer; the main accent is on the importance of development of future designer's creative skills during professional training.

Key words: art project activity, abilities, creative skills, creation, project method, future designer.

Мета: здійснити аналіз проблеми розвитку творчих здібностей майбутніх дизайнерів засобами художньо-проектної діяльності в теорії та практиці освіти.

Постановка проблеми в загальному вигляді. Вітчизняна система освіти перебуває у стані постійних змін, оновлення та реформування. Прикінцева їх мета - підвищення гарантованої якості та ефективності професійного навчання, підготовка кон-

(C) М. Тимченко курентоспроможного фахівця, здатного реалізовувати свій потенціал у нових соціально-економічних умовах, гнучко та мобільно реагувати на виклики інформаційного суспільства.

Самостійне здобування знань, систематизація їх, можливість орієнтуватися в інформаційному просторі, бачити проблему і приймати рішення можуть відбуватися саме через художню-проектну діяльність, яка в науці розглядається як феномен i фундамент культуротворчої системи загальної та професійно-технічної освіти. Художньо-проектна діяльність вимагає здатності усвідомлювати візуальну природу професійної діяльності, креативності в розв'язанні нестандартних виробничих завдань художньо-технічного напряму. У зв'язку з цим актуальним $\epsilon$ використання саме такого виду діяльності в підготовці майбутніх дизайнерів для організації художнього проектування дизайнерських продуктів відповідно до суспільно зумовлених вимог споживачів і стандартів якості.

Сьогодні недостатньо бути озброєним лише теоретичними і практичними знаннями. Конкурентоспроможним фахівець стає лише тоді, коли може використовувати отримані знання в переробленому, синтезованому вигляді. Адже споживачу та замовнику необхідно показувати щось унікальне й цікаве, яке має певну новизну. Тому необхідні творчі навички та здібності, які допомагали б майбутньому дизайнеру мислити креативно й нестандартно.

Аналіз досліджень і публікацій. Педагогічна наука приділяе значну увагу проблемі формування особистості, здатної до критичного мислення, творчої діяльності, організації самостійної роботи, самонавчання та рефлексії, що відображено в роботах I. Зязюна, С. Сисоєвої, О. Щолокової та інших. Останніми роками проблему формування творчих здібностей особистості розглядали вчені: О. Антонова, Н. Волошина, С. Гончаренко, О. Дубасенюк, О. Киричук, О.Рудницька та інші.

У частині дисертаційних досліджень останніх років, а саме: Л. Томіліної, Ю. Криворучко, Н. Кучинова, Г. Соцька, В. Чорноус, С. Шандрук, М. Якимчук, Л. Якубова та інших, представлені окремі цінні аспекти 3 проблеми формування творчих здібностей. Стимулюючий вплив художньо-проектної діяльності на розвиток творчих здібностей визначають спеціалісти в галузі мистецтвознавства: Н. Лещенко, Л. Калініченко, Л.Масол, П. Юсов та інші.

Цікавими є положення та результати експериментальних досліджень зв'язку творчих здібностей та засобів художньо-проектної діяльності через: методи активізації творчості дизайнеpa - А. Бойчук, Т. Габрель; методику навчання художнього проектування - Т. Гуменюк, А. Шевченко; підготовку майбутніх учителів - Н. Колеснік ; формування професійних умінь молодших спеціалістів-дизайнерів - 3. Макар, Цзя Яочень; формування професійної компетентності майбутніх дизайнерів - Т. Носяченко, О. Піддубної, Л. Саприкіна, О. Швець.

Виклад основного матеріалу дослідження. Концептуальні положення щодо спрямованості національної освіти на формування в учнівської молоді наукового мислення знайшли відображення в Законах України "Про освіту" [1991], "Про вищу освіту" [2000], "Про професійно-технічну освіту" [1998], а також у Державній національній програмі "Освіта" (Ук- 
раїна XXI століття) [1994], Національній доктрині розвитку освіти [2002], Концепції розвитку професійно-технічної (професійної) освіти в Україні [2004], Концепції державної програми збереження, відродження і розвитку народних художніх промислів на 2006-2010 роки [2006], постанові Кабінету Міністрів України № 37 від 20.01.1997 р. "Про першочергові заходи розвитку національної системи дизайну та ергономіки i впровадження їх досягнень у промисловому комплексі, об'єктах житлової, виробничої і соціально-культурної сфер".

Розглядаючи художньо-проектну діяльність у повному обсязі, потрібно визначити такі провідні категорії, як "проект", "метод проектів", "проектна технологія", "проектна діяльність", "проектувальна діяльність" та "художня діяльність".

Термін "проект" і "метод проектів" не $\epsilon$ інновацією у педагогіці. Але саме у XX столітті Дж. Дьюї із своїм учнем В. Х. Килпатріком запропонували цей метод як новий у педагогічній науці та впровадили його у процес навчання.

За визначенням А. Дахіна, поняття "проект" має декілька значень. Поперше, проект - це попередній (орієнтований) текст документа (проекту концепції, проекту стандарту освіти, проекту програми тощо). По-друге, проект розуміють як певну акцію, сукупність заходів, об'єднаних програмою, або організаційну форму цілеспрямованої діяльності - дослідницької діяльності тих, хто навчається. По-третє, це діяльність, спрямована на створення (вироблення, планування, конструювання) будь-якої системи, об'єкта чи моделі [7].

За цим методом група людей не лише індивідуально виконує завдання, а й має представити власний результат на загал. Також важливим позитивним моментом у методі проекту є багатокомпонентна складова. Насамперед, з одного боку, у студента постає необхідність використання різноманітних методів, засобів навчання, а 3 іншого - інтегрування знань, умінь $з$ різних галузей науки i мистецтва. Таким чином, вивчаючи одне питання, студент намагатиметься знайти інформацію з багатьох джерел, які можуть не бути пов'язані галузево, але провідна думка буде спільною.

Слід відмітити, що, за Дж. Дьюї, проектна технологія може бути не лише індивідуальною. Такі завдання часом виконуються у груповій роботі, що задовольняє та розширює: по-перше - комунікативну складову; по-друге - створюється інтеграція знань, умінь та навичок усіх учасників проекту; по-трете - розвивається дослідницька складова, яка включає $65 \%$ усього проекту, у той час як практична та оформлювальна робота $-35 \%$; творча та конструкторська діяльність [6].

Перевагою у методі проектів серед інших вважаємо активний розвиток майже всіх актуальних вмінь та навичок студента, які необхідні йому для реалізації себе як спеціаліста: планування роботи, опираючись на попередній досвід; використання великого обсягу інформації, творчий пошук та синтез отриманих знань; самостійна робота над пошуком матеріалу; аналіз та синтезування інформації; прийняття рішення, яке стосується подальшого виконання проекту, його реалізації; утворення стійких комунікативних зв'язків між членами групи, де ведеться пошукова робота; створення "кінцевого продукту" як кінечний результат діяльності; презентація проекту перед аудиторією; оцінка своєї діяльності [6].

Отже, завдяки цим видам діяльності студент уже на етапі навчання та розробки навчального проекту моделює власний робочий процес, та не просто виконує навчальну та виконавську функції, але й занурюється у професійні ситуації, що надалі допоможуть у становленні фахівця своєї справи.

Тому як сьогодні, так і в минулому передумовами для появи методу проектів в освіті послужили соціально-економічні умови, які спричинили потребу в перегляді традиційних методів навчання у зв'язку з необхідністю задоволення запитів нового часу з підготовки фахівців [6]. Така діяльність пронизує всі сфери функціонування промислового підприємства: у маркетингу - це проекти маркетингових досліджень, рекламних акцій, виведення на ринок нових продуктів, завоювання нових ринків збуту; у дослідно-конструкторських підрозділах, зокрема у дизайні, - це проекти розробки нових продуктів, технологій; на виробництві - проекти освоєння випуску нової продукції, технічного переозброєння, упровадження нових технологій [2]. Отже, проектна діяльність займає провідне місце в розвитку дизайнера як фахівця. Але разом з тим створення дизайнерського проекту не можливе без урахування художньої та творчої складової.

Однак у роботі дизайнера невід'ємною складовою $є$ художня діяльність, оскільки людина цієї галузі має оперувати знаннями про загальні закономірності художнього осмислення дійсності, сутність і форми відображення реальності і перетворення життя за законами краси, про роль мистецтва в розвитку суспільства.

Власне, художньо-естетичний напрям не тільки відкриває душу назустріч звукам, фарбам, формам світу та мистецтву, але й загалом сприяе більш повному, зв'язному i глибокому розумінню світу, більш гармонійному, усебічному розкриттю самого себе. Це веде до розвитку творчого мислення, розширює можливості в пошуку нових шляхів i рішень, у тому числі у сфері дизайну. У теорії естетичного виховання творчо-естетична діяльність розглядається на основі активізації емоційного досвіду особистості, в органічній єдності емоційно-почуттєвої та інтелектуальної сфер (В. Бутенко, Т. Зайцева, О. Олексюк, Г. Падалка, Л. Рожина, Л. Фаустова, Г. Шевченко, О. Щолокова та ін.). Саме тому важливо звертати увагу не лише на змістову частину проекту, а й мистецьку складову: наскільки креативно та творчо був виконаний проект, які новітні ідей він несе, на які емоційно-чутливі сфери впливає.

У дизайн-освіті навчання майбутніх дизайнерів методом проектів відбувається за логікою створення презентаційного проекту відповідно до художньої композиції. У художньому мистецтві у процесі створення проектів враховується його художньо-ціннісна інтерпретація та композиційно-кольорове оформлення. Саме тому можна зробити висновок, що проектування в галузі мистецтва передбачає необхідність поєднувати логічний і художній аспекти.

Особливу увагу слід звернути на роботи, що розкривають художньотворчу складову проектної діяльності, а саме:

- характерні риси та властивості використання методу творчих проектів (О. Омельчук);

• вплив художньо-проектної діяльності на естетизацію особистості (М. Курач); 
- теоретико-методологічні основи реалізації творчих проектів у навчальному процесі сучасної школи (C. Ізбаш).

На сьогоднішній момент художньо-проектну діяльність досліджують такі вчені, як А. Бровченко, В. Даниленко, А. Король, С. Пащенко, Т. Сенчук. Вони зазначають, що художньопроектна діяльність, яка спрямована на пошук та синтез інформації із подальшим іiї творчим перетворенням, дозволяє максимально яскраво презентувати власну творчу ідею, застосовуючи вже раніше отримані знанНЯ.

К. Вітчинкіна дає таке визначення художньо-проектній діяльності: це творчий метод, процес i результат художньо-технічного проектування промислових виробів, їхніх комплексів і систем, орієнтований на досягнення відповідності створюваних об'єктів і середовища загалом потребам людини - як утилітарних, так і естетичних [ 5].

Потенціал художньо-проектної діяльності студентів у процесі естетизації навчально-виховного процесу є об'єктом дослідження М. Курач. Автор наголошує, що даний вид діяльності впливає на розвиток естетичних смаків, ідеалів, почуттів, естетичної культури та естетичної свідомості студентів, що в перспективі трансформуватиметься у їхню готовність траслювання отриманих установок та світогляду [8].

Художні образи, які передають твори мистецтва, впливають на художній світогляд особистості, який $є$ специфічною формою емоційноціннісного ставлення до навколишнього буття, фокусуючи смисложиттєві установки та орієнтири людини [12].

Саме тому необхідно вести мову про художньо-проектну діяльність майбутніх дизайнерів, де у змістовій лінії проекту відбувається поєднання інтелектуального, творчого, естетичного та художнього пізнання світу.

На основі цього доходимо висновку, що художньо-проектна діяльність майбутніх дизайнерів має передбачати наступні компоненти: осмислення ролі художніх образів дизайну у змістовому наповненні проектів; виявлення емоційноціннісного потенціалу образів мистецтва у процесі створення проекту; створення цілісної художньо-змістової лінії проекту з рівноцінним інтелектуальним (теоретичний) та художньо-естетичним впливом.
У теперішній час наше суспільство вимагає не просто теоретично озброєного виконавця, а i справжнього професіонала своєї справи, котрий був би готовим не лише виконувати поставлені завдання, а й ставити собі робочі цілі самостійно. Для цього необхідний певний елемент творчості та креативності в мисленнєвому процесі та подальшій діяльності. Отож постає питання про розвиток не просто конструкторських умінь, які, по суті, є лише загальними здібностями та належать до рівня "навченості", а й про посилену увагу до розвитку творчих здібностей особистості, формування компетентності та креативності в майбутніх фахівців.

Скрипченко О. В. зазначає, що здібності - індивідуально-психологічні особливості, які є умовою успішного здійснення певної діяльності. Вони не можуть бути зведені до знань, умінь і навичок, що $є$ у людини, але здібності забезпечують їх швидке набуття, фіксацію й ефективне практичне застосування [11].

T. Равлюк розглядає творчі здібності як синтез властивостей особистості, що характеризуються ступенем відповідності певного виду творчої діяльності вимогам до неї та зумовлюють результативність такої діяльності [9]. Вирішення проблеми формування творчих здібностей майбутніх дизайнерів певною мірою заповнює прогалини в культурно ціннісній сфері дизайну, сприяє створенню науково обгрунтованої концепції розвитку дизайн-освіти в умовах суперечливих тенденцій девальвації традиційних базових цінностей. Одночасно з цим закладаються основи для розробки інноваційних педагогічних технологій у підготовці кваліфікованих дизайнерів. Завдяки таким новаціям має бути встановлений баланс між художньо-естетичною i промислово-технічною складовими професійної підготовки майбутнього спеціаліста.

Студентський вік характеризується сенситивним періодом для розвитку творчості не на інтуїтивному рівні, а на усвідомленні власних дій та їх результатів, наявності певного підгрунтя знань, опираючись на які, студент зможе генерувати креативні ідеї. У вищому мистецькому навчальному закладі $\epsilon$ всі передумови для позитивного розвитку та розширення як власних здібностей, так і творчих. Насамперед, це постійна завантаженість багатоплановим творчим навчальним матеріалом, який пов'язаний тематично, завдання, які вимагають не лише технічних умінь, але $\mathrm{i}$ стимулюють до творчості. Подібні завдання та вправи не лише допомагають виробити професійні навички, але й формують творчі якості особистості, зокрема, нестандартні підходи до звичних завдань, що допомагають самовизначитись і самореалізуватись особистості в культурі.

Виходячи $з$ висловленого, ми можемо говорити про розвиток творчих здібностей у майбутніх дизайнерів. Завдяки художньо-проектній діяльності студент спрямовує свої дії на розширення знань, пошук себе у сфері мистецтва, власного стилю, що в результаті сприяє появі відчуття форми, кольору, творчої уяви, образів відповідно до сформованих естетичних ідеалів, смаків. Водночас засвоюються традиції декоративноприкладного та образотворчого мистецтва, і на цій основі нагромаджується власний творчий потенціал, спрямований на художнє проектування і виготовлення мистецьких творів.

Самостійне здобування знань, систематизація їх, можливість орієнтуватися в інформаційному просторі, бачити проблему і приймати рішення може відбуватися саме через художню-проектну діяльность, яка в науці розглядається як феномен i фундамент культуротворчої системи загальної та професійно-технічної освіти. Художньо-проектна діяльність вимагає від майбутнього фахівця здатності усвідомлювати візуальну природу професійної діяльності, креативності в розв'язанні нестандартних виробничих завдань художньо-технічного змісту. Звідси актуальним вважаємо використання саме такого виду діяльності в підготовці студентів для організації художнього проектування дизайнерських продуктів відповідно до суспільно зумовлених вимог споживачів і стандартів якості.

Висновки та перспективи подальших досліджень. Отже, викладене нами дозволяє дійти до узагальнення, що на даному етапі розвитку українського суспільства актуальною залишається проблема розвитку творчих здібностей людини. Для того, щоб задовольнити потреби і запити 3 боку ринку парці, самореалізовуватись у найбільш цікавій для себе сфері, людині необхідно здобувати багато інформації, удосконалюючи тим самим свої уміння і навички. 
Однак недостатнім бачиться озброєння лише технічними навичками роботи, необхідно творчо та креативно застосовувати свій знаннєвий арсенал для досягнення найкращого результату. Звідси й постає необхідність розвитку творчих здібностей.

\section{ЛІТЕРАТУРА}

1. Дубасенюк О. А. Професійна педагогічна освіта: методологія. теорія, практика : монографія. Житомир : Вид-во ЖДУ ім. І. Франка, 2016. Т. 2. $376 \mathrm{c}$.

2. Батенко Л. П., Загородніх О. А., Ліщинська В. В. // Управління проектами: навч. посібник. Київ : КНЕУ, 2003. $231 \mathrm{c}$

3. Березюк О. С. Моделювання педагогічних ситуацій у фаховій підготовці майбутнього спеціаліста. Житомир : Вид-во ЖДУ ім. І. Франка, 2012. 160 с.

4. Богоявленская Д. Б. О предмете и методе исследования творческих способностей. Псих. журнал. 1995. №6. C. 49-58.

5. Вітчинкіна К. О. Обгрунтування дизайну як творчої проектно-художньої діяльності. Вісник ХДАДМ. 2009. № 8. C. 23-27.

6. Игнатова И. Б. Проектные технологии как метод обучения: историко-.педагогический анализ. URL: http://teoriapractica.ru/rus/files/ arhiv_zhurnala/2011/1/pedagogika/ ignatova sushkova.pdf

7. Ковшун Н. Е. Аналіз та планування проектів: навчальний посібник. Київ : Центр учбової літератури, 2008. $344 \mathrm{c}$

8. Курач М. С. Компоненти педагогічної концепції формування цілісного художньо-проектного знання майбутнього вчителя технологій. Проблеми підготовки сучасного вчителя : збірник наукових праць Уманського державного педагогічного університету імені Павла Тичини / ред. кол. : Побірченко Н. С. (гол. ред.) та інші. Умань : ППЖовтий, 2014.
№ 10 (Ч. 3). С. 49-53

9. Равлюк Т. Діагностика та раннє виявлення творчих здібностей учнів. Вісник Львів. ун-ту. 2005. Вип. 20. С. 112-118.

10. Оружа Л. В. Розвиток дизайнерської освіти в світі. Науковий часопис Національного педагогічного університету імені М. П. Драгоманова. Серія 5: Педагогічні науки: реалії та перспективи: Київ : Видво НПУ ім. М. П. Драгоманова, 2010. Вип. 24. С. 168-172

11. Скрипченко О. В., Л. В. Долинська, 3. В. Огороднійчук, Т. М. Лисянська. Загальна психологія: підручник. Київ : Либідь, 2005. С. 464.

12. Топчієва, I. О. Розвиток творчої індивідуальності студентів факультету мистецтв засобами проектних технологій. Єдність навчання $\mathrm{i}$ наукових досліджень - головний принцип університету : матеріали звітної науково-практичної конференції, 14-18 березня 2016 року. Київ : Вид-во НПУ імені М. П. Драгоманова, 2016. С. 111-113.

\section{REFERENCES}

1. Dubasenyuk O. A. Profesiyna pedagogichna osvita: metodologiya. teoriya, praktika : monografiya. Zhitomir : Vid-vo ZhDU Im. I. Franka, 2016. $376 \mathrm{~s}$.

2. Batenko L. P., Zagorodnih O. A., Lischinska V. V. Upravlinnya proektami: Navch. posIbnik. K.: KNEU, 2003. $231 \mathrm{~s}$

3. Berezyuk O.S. Modelyuvannya pedagogichnih situatsiy u fahoviy pidgotovtsi maybutnogo spetsialista. - Zhitomir : Vid-vo ZhDU Im. I. Franka, 2012. $160 \mathrm{~s}$.

4. Bogoyavlenskaya D. B. O predmete i metode issledovaniya tvorcheskih sposobnostey // Psih. zhurnal. 1995. № 6. S. 49-58.

5. Vitchinkina K.O. Obgruntuvannya dizaynu yak tvorchoyi proektno-hudozhnoyi diyalnosti. Visnik HDADM. 2009. № 8.
S. 23-27.

6. Ignatova I. B. Proektnyie tehnologii kak metod obucheniya: istoriko-.pedagogicheskiy analiz URL: http://teoriapractica.ru/rus/files/ arhiv_zhurnala/2011/1/pedagogika/ ignatova sushkova.pdf

7. Kovshun N. E. Analiz ta planuvannya proektIv: navchalniy posibnik. K.: Tsentr uchbovoyi literaturi, 2008. $344 \mathrm{~s}$.

8. Kurach M. S., Shabaga S. B. Komponenti pedagogichnoyi kontseptsiyi formuvannya tsinisnogo hudozhno-proektnogo znannya maybutnogo vchitelya tehnologIy. Problemi pidgotovki suchasnogo vchitelya : zbirnik naukovih prats Umanskogo derzhavnogo pedagogichnogo universitetu Imeni Pavla Tichini / red. kol. : N. S. Pobirchenko (gol. red.) ta inshi. Uman : PP Zhovtiy, 2014. № 10. Ch. 3. S. 49-53.

9. Ravlyuk T. Diagnostika ta ranne viyavlennya tvorchih zdIbnostey uchnIv. VIsnik Lviv. un-tu. 2005. Vip. 20. S. $112-118$.

10. Oruzha L. V. Rozvitok dizaynerskoYi osviti v svItI. Naukoviy chasopis NatsIonalnogo pedagogIchnogo unIversitetu Imeni M. P. Dragomanova. Seriya 5 . Pedagogichni nauki: realiyi ta perspektivi. K.: Vidvo NPU Im. M.P. Dragomanova, 2010. Vip. 24. S.168-172

11. Skripchenko O. V., Dolinska L. V., Ogorodniychuk 3. V., Lisyanska T. M. Zagalna psihologiya: pidruchnik. K.: Libid, 2005. S. 464.

12. Topchieva I. O. Rozvitok tvorchoyi Individualnosti studentiv fakultetu mistetstv zasobami proektnih tehnologiy. Ednist navchannya i naukovih doslidzhen - golovniy printsip universitetu : materlali zvitnoyi naukovo-praktichnoyi konferentsiyi. 14-18 bereznya 2016 roku. K. : Vid-vo NPU ImenI M. P. Dragomanova, 2016. C. 111-113.

Стаття надійшла 7.05.2019 р. 